Proc. Estonian Acad. Sci. Biol. Ecol., 2002, 51, 1, 74-84

\title{
Influence of water level on fish stocks and catches in Lake Võrtsjärv
}

\author{
Ain Järvalt and Ervin Pihu \\ Võrtsjärv Limnological Station, Institute of Zoology and Botany, Estonian Agricultural University, \\ 61101 Rannu, Tartumaa, Estonia; ajarvalt@zbi.ee
}

Received 5 July 2001, in revised form 20 November 2001

\begin{abstract}
Lake Võrtsjärv is a large (area $270 \mathrm{~km}^{2}$ ) shallow (maximum depth $6.0 \mathrm{~m}$ ) eutrophic lake. Eel, pikeperch, bream, and pike are the main commercial fishes in the lake, while perch, roach, ruffe, and burbot are of secondary economic importance. High water level in the lake in spring expands the spawning areas of pike and has a strong positive influence on the abundance of a new pike generation. Bream catches are larger at high water level, when traps can be placed nearer to the spawning places of this fish. High water favours formation of strong generations of burbot, which prefers cold water. Abundant generations of pikeperch originate from the years of low water level in the lake, when spawning occurs at an earlier time and pikeperch fingerlings grow more rapidly and pass over to feeding on prey already in their first summer of life. With low water level and severe winter fish kills may occur in the lake.
\end{abstract}

Key words: Lake Võrtsjärv, water level, pike, bream, burbot, pikeperch, winter kills.

\section{INTRODUCTION}

Formation of the composition and abundance of fish species in a water body is determined by a complex of natural conditions (lake area, depth, water temperature, trophy) on the one hand and by the intensity and methods of fishing on the other hand (Leach et al., 1987; Le Cren, 1987; Mills \& Hurley, 1990; Downing \& Plante, 1993). The population structure of many commercial species often shows strong year-classes, which persist in catches over several years and appear unrelated to parental numbers. In some cases strong recruitments occur periodically when several favourable aspects of the environment coincide (King, 1997). In temperate waters the year-class strength is directly influenced by the water temperature (Mills \& Hurley, 1990; Downing \& Plante, 1993; Lehtonen et al., 1993; Wolnicki et al., 2001). Change in water level is one of the most important factors influencing the ecosystem and management of a shallow lake (Huttula \& Nõges, 1998; Nõges \& Nõges, 1998; Nõges et al., 2000). 
Lake Võrtsjärv has a high recreational and fishery value as well as a considerable navigational importance. As the lake is shallow, low level periods are accompanied by several phenomena detrimental to its ecosystem, such as cyanophyte blooms, overgrowing with macrophytes, restricted spawning places for pike, and winter fish kills (Nõges \& Nõges, 1998; Kangur et al., 2000). In the years of low water level the fishing opportunities in established sites using particular gear as well as access to harbours are hindered. With high water level, the flooding of large areas causes problems mainly for agriculture and forestry.

The aim of the present study was to evaluate the effect of water level changes on the stocks and catches of fish in a large and shallow lake.

\section{MATERIAL AND METHODS}

Daily registration of water level at the outflow of L. Võrtsjärv at RannuJõesuu was started in 1921. Earlier water levels, starting from 1885, were calculated on the basis of data from the hydrological station of the Emajoggi River in Tartu (Huttula \& Nõges, 1998). Zero water level for the Rannu-Jõesuu hydrological station is $33.63 \mathrm{~m}$ above mean sea level according to the Baltic System (BS). The statistics of commercial fish catches from 1971 to 2000 was used. During this period only passive fishing gear (fish traps and gill nets) was used and the intensity of fishing remained at a more or less constant level. At the beginning of the 1990s pikeperch catches, in particular, were not completely registered in connection with profound changes in economic life and a rapid rise in prices (Järvalt, 1998). A sampling strategy of experimental trawling was applied from 1978. During the ice-free period (April-November) fish was caught with an experimental trawl (mesh size $10 \mathrm{~mm}$ in the cod-end, measured between adjacent knots) at three sample sites (in southern, central, and northern parts of the lake) three times per month. Catch data per unit effort (CPUE) of experimental trawl were calculated in kilograms per trawl-hour. Linear correlation analysis was used to evaluate the significance of differences between water level and fish catches (Kiviste, 1999). The differences were considered significant at $P \leq 0.05$.

\section{THE STUDY SITE}

Lake Võrtsjärv is a large shallow eutrophic lake. Its drainage basin $\left(3104 \mathrm{~km}^{2}\right.$, from this $103 \mathrm{~km}^{2}$ in Latvia) is situated in the Central Estonian depression of preglacial origin. According to the official registry of the Estonian streams (Arukaevu, 1986) five rivers, seven brooks, nine major ditches, and many smaller ditches flow into L. Võrtsjärv. The main inflows (regarding their flow rate) are the rivers of Väike Emajõgi, Õhne, Tänassilma, Rõngu, and Tarvastu. The outflow into L. Peipsi occurs via the Emajõgi River (Fig. 1). During spring floods the direction of the flow in this river may be reversed in its upper course (usually for two weeks). This phenomenon prolongs the duration of the high level period of the lake. 


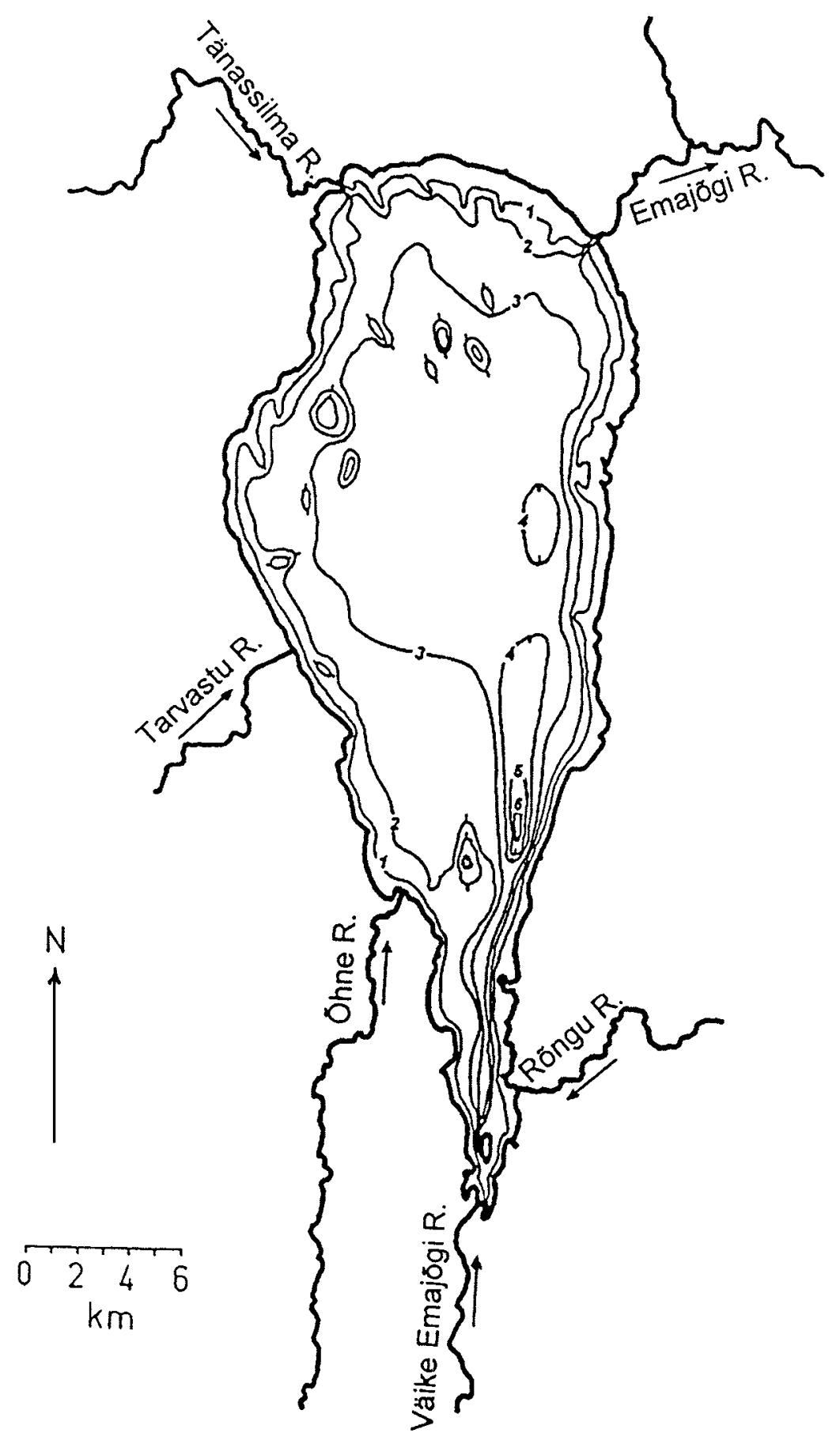

Fig. 1. Bathymetric map of L. Võrtsjärv with the main inflows and outflow. 
The long-term mean level of L. Võrtsjärv for the period 1922-98 is $33.63 \mathrm{~m}$ BS above mean sea level (Järvet, 2000). In the case of this water level the surface area of the lake is about $270 \mathrm{~km}^{2}$, and the mean and maximum depths are 2.8 and $6.0 \mathrm{~m}$, respectively.

The mean annual amplitude of water level fluctuation in L. Vorrtsjärv is $1.34 \mathrm{~m}$. The minimum amplitude of $0.75 \mathrm{~m}$ was registered in 1925 and the maximum, $2.02 \mathrm{~m}$, in 1951. The absolute long-term range of water level fluctuations is $3.08 \mathrm{~m}: 35.28 \mathrm{~m}$ BS in 1923 and $32.20 \mathrm{~m}$ BS in 1996. In the case of these water level extremes the lake's area varies about 1.4 times $\left(237-326 \mathrm{~km}^{2}\right)$ and volume 3.2 times (0.383-1.213 $\left.\mathrm{km}^{3}\right)$ (Järvet, 2000).

In the long term, the water level of L. Võrtsjärv has revealed sinusoidal fluctuations: five low level periods and four high level periods with a duration of 25-30 years each have alternated since 1885 (Fig. 2). At present the water level of the lake has recovered after the extremely low level of 1996.

As a rule, the water level of L. Võrtsjärv is relatively low in winter and high in spring, decreases gradually during summer and early autumn, and has a slight rise in late autumn (Fig. 3).

The flooding of meadows surrounding L. Võrtsjärv starts at a water level of $34.47 \mathrm{~cm}$ BS (Pihu, 1959). Lakeside areas are usually inundated from mid-April to the second half of June. At the highest water level the submerged area exceeds $50 \mathrm{~km}^{2}$ (Jaani, 1973). In dry springs no flooding occurs.

In 1965 macrophytes covered only 15\% of the lake's area (Mäemets, 1973), since then their area has expanded markedly (Haberman et al., 1998). Because of the prevalence of westerly winds, the reed belt (mainly Phragmites australis and

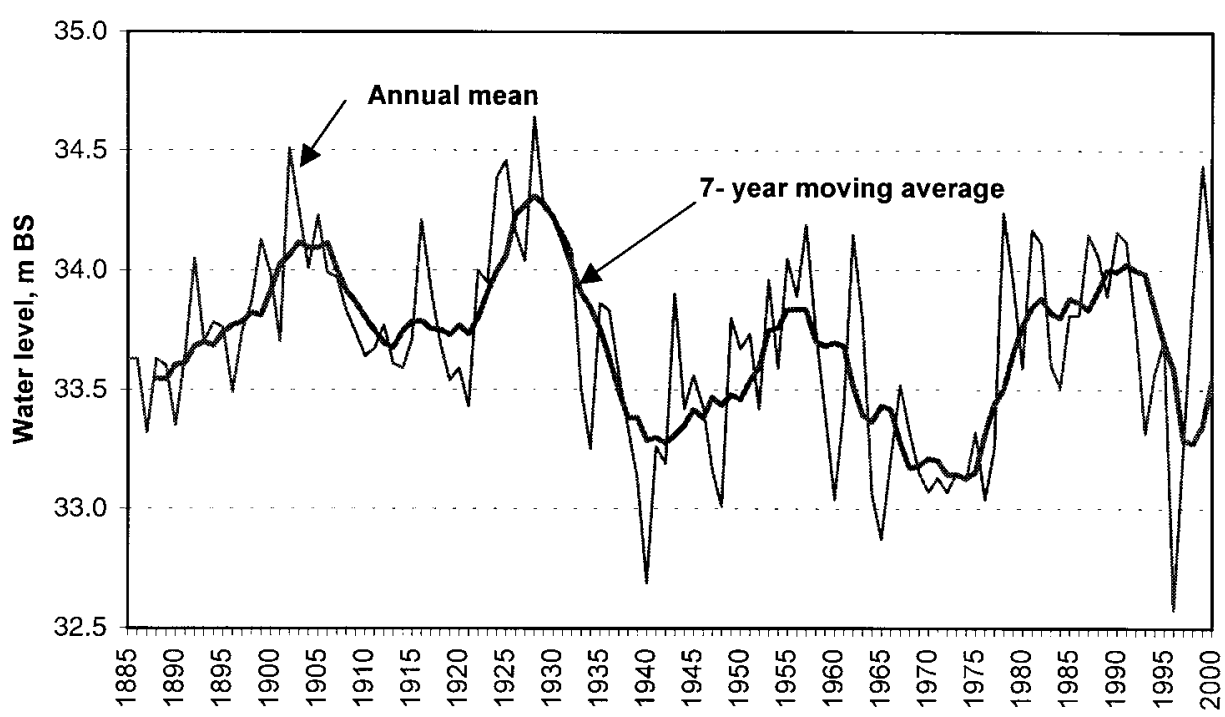

Fig. 2. Long-term changes in the mean annual water level of L. Võrtsjärv (1885-2000). 


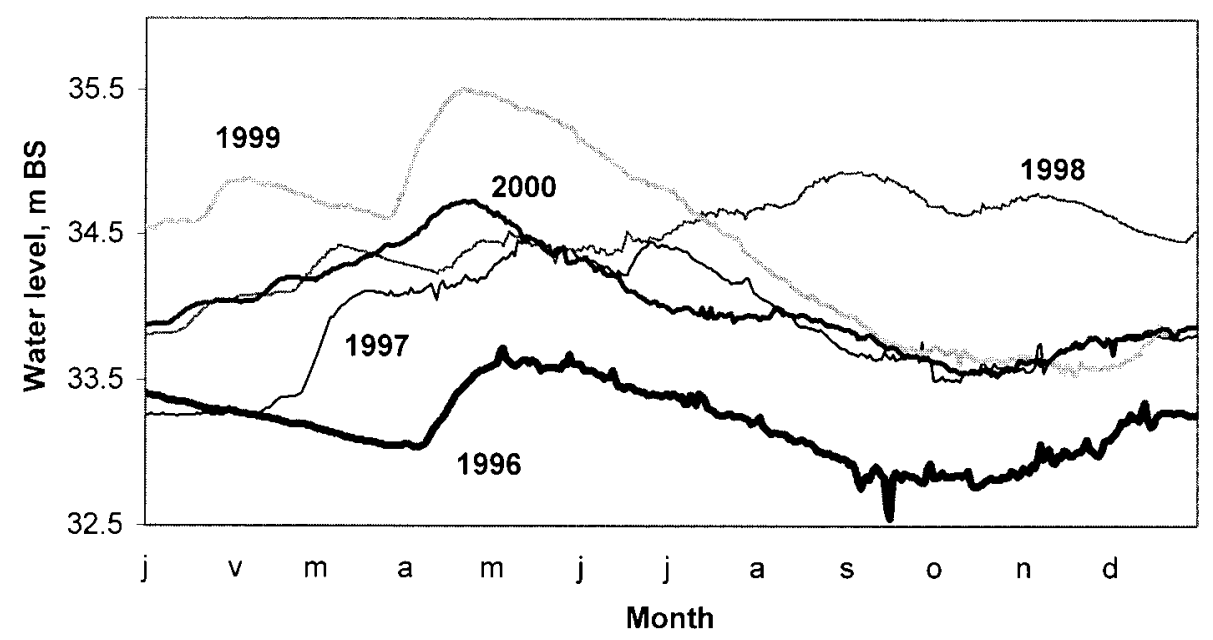

Fig. 3. Seasonal changes in the water level of L. Võrtsjärv in 1996-2000.

Schoenoplectus lacustris) is continuous and lush at the sheltered western shore and broken at the open eastern shore. The narrow southern tip of L. Võrtsjärv is fully grown over with macrophytes (Nuphar lutea and Potamogeton lucens are prevailing).

\section{RESULTS AND DISCUSSION}

\section{Fish composition and fishery}

According to current data, one lamprey species (Lampetra planeri) and 31 fish species inhabit permanently L. Võrtsjärv (Pihu, 1998). Bream, eel, pikeperch, and pike are the main commercial fishes, while perch, roach, ruffe, and burbot are of secondary economic importance. According to fishery classification, L. Võrtsjärv belongs to pikeperch lakes. It has all the qualities characterizing such lakes. The water is shallow, relatively warm, and turbid (Secchi depth $0.5-1.0 \mathrm{~m}$ ) in summer. The lake (except for its southern part) is rather poor in vegetation. Its northern part with a sandy and stony bottom offers many good spawning places for pikeperch. It has also favourable feeding conditions because of sufficient amounts of small and easily accessible lake smelt and the fry of other fishes.

However, in the 1950s and 1960s L. Võrtsjärv was regarded as a ruffe lake, because the bulk of the fish caught there consisted of ruffe, young perch, and roach (Table 1). Attempts to reduce the abundance of these undesirable fishes by intensive trawling were unsuccessful. Fine-meshed trawls damaged the stocks of valuable fish (first of all, pikeperch) as a consequence of which their numbers became scanty (except in the case of bream). At the end of the 1960s trawling was stopped, elvers were regularly introduced into the lake, and the protection of 
Table 1. Fish catches in Lake Võrtsjärv

\begin{tabular}{c|c|r|r|r|r|r}
\hline \multirow{2}{*}{ Fish } & \multicolumn{7}{c}{ Period } \\
\cline { 2 - 7 } & $1952-68$ & $1969-80$ & $1981-85$ & $1986-90$ & $1991-95$ & $1996-2000$ \\
\hline Commercial fishes, t & 61 & 117 & 212 & 308 & 198 & 161 \\
Eel & 1.0 & 24 & 38 & 65 & 41 & 34 \\
Pike & 15 & 14 & 41 & 49 & 26 & 24 \\
Bream & 24 & 28 & 66 & 134 & 95 & 65 \\
Pikeperch & 5 & 43 & 49 & 46 & 25 & 28 \\
Perch > 12 cm & 11 & 4 & 8 & 7 & 6 & 7 \\
Burbot and others & 5 & 4 & 10 & 7 & 5 & 3 \\
Small inferior fishes, t & 249 & 70 & 108 & 230 & 122 & 105 \\
& & & & & & \\
Total annual catch, t & 310 & 187 & 320 & 538 & 320 & 266 \\
Total annual catch, kg ha ${ }^{-1}$ & 11.5 & 6.9 & 11.9 & 19.9 & 11.8 & 9.9
\end{tabular}

commercial fishes was improved. As a result of these measures, the total catch of fish decreased in the 1970s, but the stocks and catches of commercial fishes (above all those of pikeperch and eel) began to grow rapidly (Pihu, 1998). The increasing pressure of predatory fishes (mainly pikeperch and pike) led to an abrupt reduction in the abundance of less valuable small fishes.

In the 1950s and 1960s macrozoobenthos was quite scanty in L. Võrtsjärv, its average biomass being only $3-4 \mathrm{~g} \mathrm{~m}^{-2}$ (Kangur et al., 1998). Therefore bream became a serious competitor for the much more valuable eel. In 1978 all catch limitations on bream were abolished. Since the 1980s the catches of small fish have again increased, but they consist mainly of small bream, not ruffe, small perch, and roach as previously. Unlimited catch had a positive effect on the bream population: its growth rate has accelerated and the quality of its flesh has improved.

Subsequently, the condition of macrozoobenthos has somewhat improved. In recent decades its biomass has been estimated mostly at 5-7 $\mathrm{g} \mathrm{m}^{-2}$, of which Chironomus plumosus (the favourite food item for benthophagous fishes) usually accounts for 70-80\% (Kangur et al., 1998). As a result, L. Võrtsjärv has by now acquired also some qualities of a bream lake. Bream has favourable spawning conditions here; nowadays it is the most abundant species among the valuable big commercial fishes of the lake.

The eel production of L. Vorrtsjärv is entirely based on stocking with wild caught elvers (42 million during 1956-2001). In 1988, the maximum annual catch of eel exceeded $100 \mathrm{t}$. Although in the 1990s the reported annual catch of eel was only $22-49 \mathrm{t}$, its real catch was far larger.

According to official data (Table 1) the catch of fish in L. Võrtsjärv decreased somewhat in the 1990s. The real catch has been underestimated due to the rearrangement of the fishery management of the lake after Estonia regained independence in 1991. The previous socialist fishery farms split into cooperatives, 
as a result of which fish catches have not been adequately registered. In any case it is certain that since 1991-92 fish catches have not essentially decreased in the lake.

\section{Water level and catches of fish}

Water level is one of the main factors determining to a great extent the success of spawning and hence the abundance and catches of many fish species. In L. Võrtsjärv water level has a particularly significant effect on the abundance of pike, which lays its eggs in flooded shallow places (as a rule, up to $0.5 \mathrm{~m}$ ), mostly on dead vegetation. In the case of high water level, the spawning areas of pike are rather extensive, which lays a firm foundation for the formation of a strong pike generation. There is an evident positive correlation $(r=0.45 ; n=30$; $p<0.01$ ) between the mean water level in spring and pike catch in the lake (Figs. 4, 5). As a rule, abundant pike catches follow, with a 4-5-year delay, periods of high water level, and small catches occur, with a similar delay, after periods of low water level. This is in accordance with the age composition of pike catches in L. Võrtsjärv, where usually 4-5-year-old specimens are dominating. On the ground of an experimental trawl catch a still stronger positive correlation $(r=0.61 ; n=23 ; p<0.01)$ was found between the abundance of a particular pike generation and water level in the spawning period (April-May) in the lake. A significant positive correlation between the water level in spring and annual catch of pike was found also in L. Peipsi (Kangur et al., 2000).

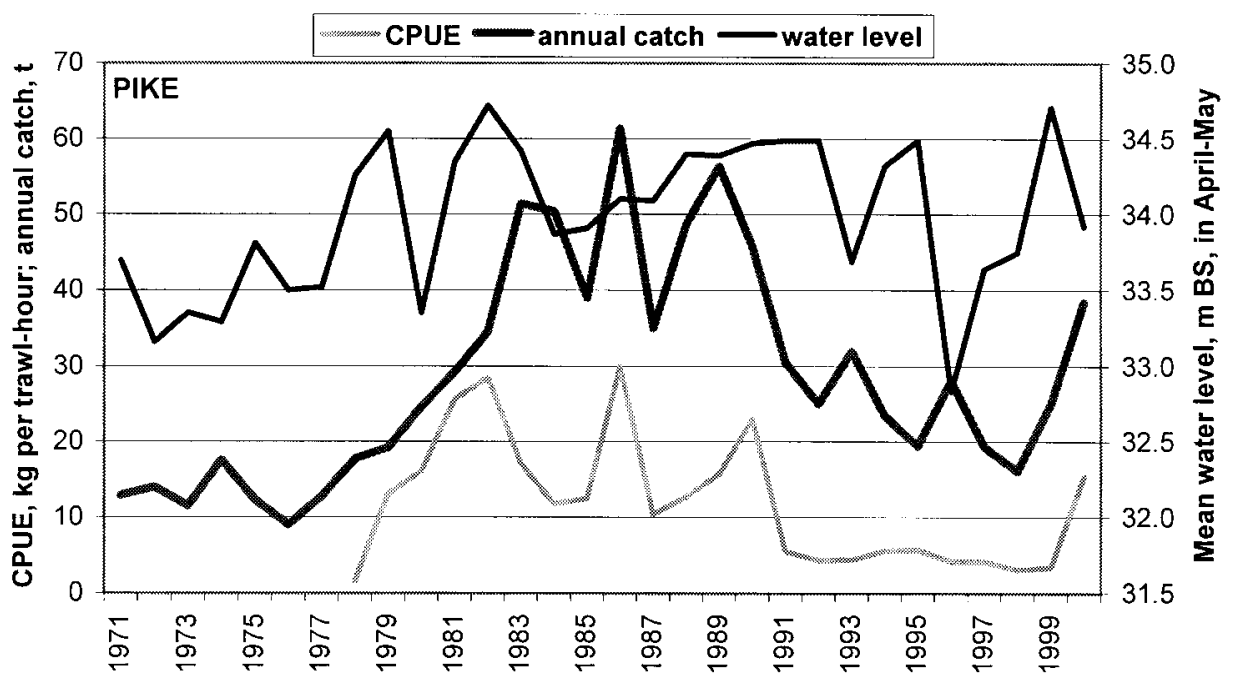

Fig. 4. Fluctuations of the water level in spring, and commercial and experimental trawl catches of pike from L. Võrtsjärv. 


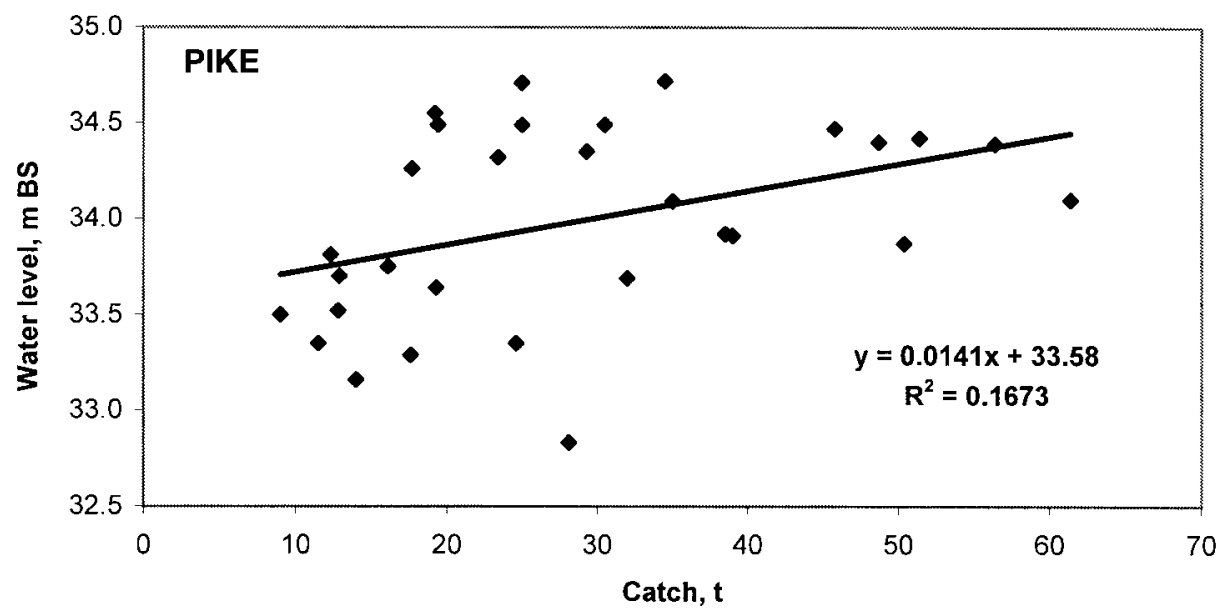

Fig. 5. Relationship between the mean water level in spring (1967-96) and commercial catches of pike four years later (1971-2000) in L. Võrtsjärv.

Annual bream catches also depend on water level in L. Võrtsjärv (Fig. 6), being greater with higher level $(r=0.46 ; n=30 ; p<0.01)$. As a rule, about a half of the annual catch of bream is landed in spring during its spawning period with traps. In the case of high water level traps are placed nearer to the shore

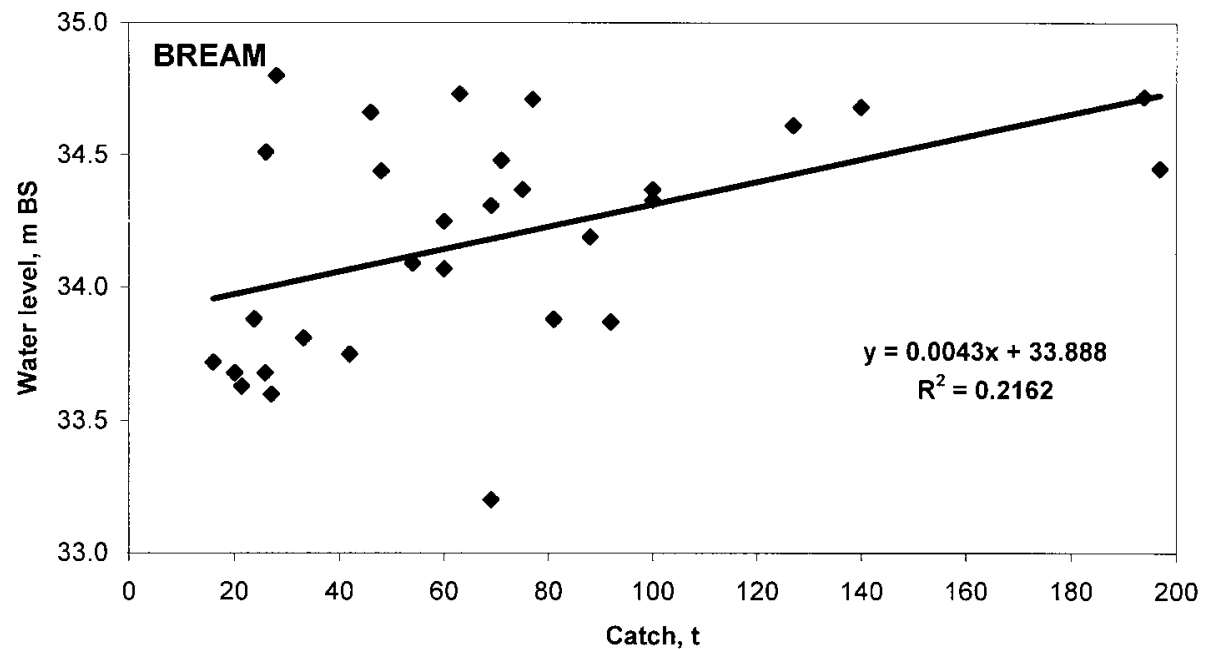

Fig. 6. Relationship between the annual mean water level and catches of bream in L. Vorrtsjärv in 1971-2000. 
and hence nearer to the spawning places of bream. Unlike for pike, no reliable correlation was found between water level and annual catches of bream: this fish has a sufficient number of suitable spawning places both with high and with low water in the lake.

High water periods favour the formation of strong generations of burbot $(r=0.33 ; n=30 ; p<0.05)$ in L. Võrtsjärv. Being a fish of northern origin, burbot prefers cold water (Wolnicki et al., 2001).

As a rule, strong generations of pikeperch originate from the years of low water level in L. Võrtsjärv $(r=0.42 ; n=23 ; p<0.05)$. At low level, water warms up sooner, spawning occurs earlier, and the fry of pikeperch has a longer growing period. In a warm spring and summer the fingerlings of pikeperch give up feeding on zooplankton already in August-September and pass over to preying on the tiny and accessible fry of lake smelt. As a result of piscivorous feeding the growth rate of pikeperch fingerlings increases rapidly, and they reach the standard length of $10-12 \mathrm{~cm}$ by early winter. In a cool spring and summer, pikeperch fingerlings are forced to feed on zooplankton during their first year of life, they grow slowly, reaching a length of mere 5.5-6.5 cm in November (Erm, 1981; Järvalt, 1990, 1998), and become predators only in the following year. Small fingerlings have a very high mortality (up to $90 \%$ ) during their first winter.

On the ground of the present data, annual pikeperch catches do not depend significantly $(r=0.25)$ on the mean annual water level in L. Võrtsjärv $(r=0.31$; $n=30 ; p<0.05)$. Still, a very strong positive correlation $(r=0.57 ; n=24$; $p<0.01)$ was found between the experimental trawl catches of pikeperch and water level in the lake (Fig. 7).

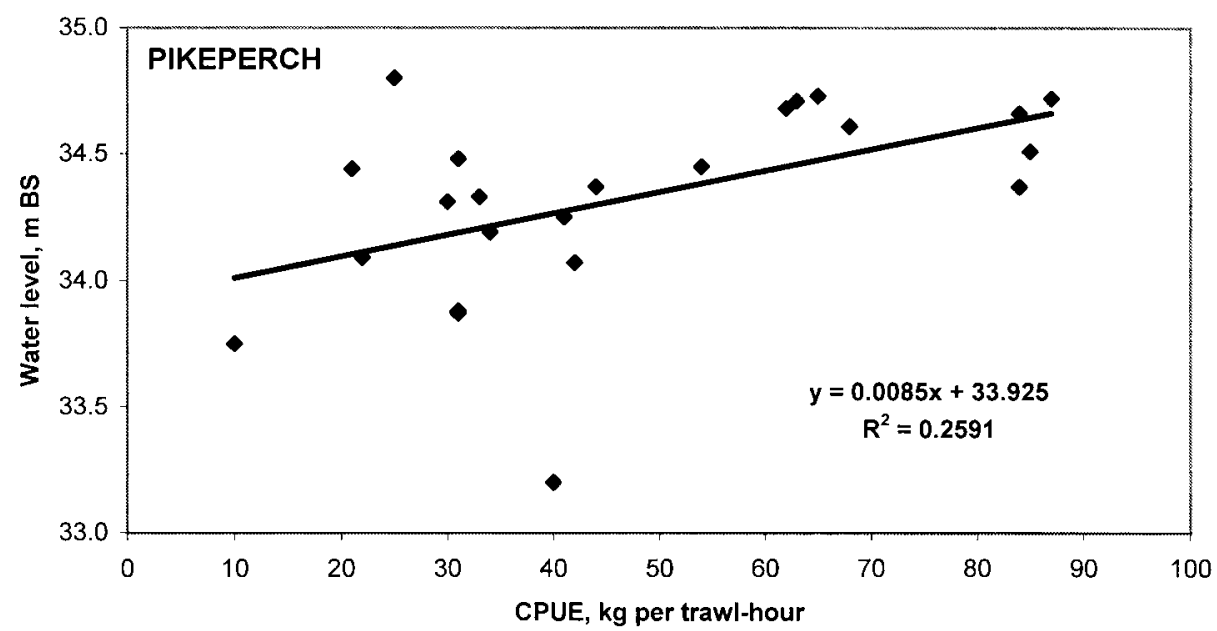

Fig. 7. Relationship between the annual mean water level and experimental trawl catches of pikeperch in L. Võrtsjärv in 1978-2000. 


\section{Winter kills of fish and water level}

In case a low water level and a severe winter coincide, serious fish kills may occur in L. Võrtsjärv. An analysis made by Nõges \& Nõges (1998) revealed a significantly lower water level in the years of fish kills, especially in the winter months. Thus, in the early spring of 1996 when the water level was close to its absolute minimum in the lake (average $-0.41 \mathrm{~m}$ BS during January-March) and the winter was extraordinarily cold, the southern and southwestern shallow lake parts were frozen to bottom. The lake was covered with thick ice $(0.6 \mathrm{~m})$ and snow $(0.3 \mathrm{~m})$, and the lowest oxygen concentration during the studied 30 years $\left(2.3 \mathrm{mg} \mathrm{O}_{2} \mathrm{~L}^{-1}\right)$ was registered directly under the ice $\left(0.4 \mathrm{mg} \mathrm{O}_{2} \mathrm{~L}^{-1}\right.$ in the bottom layer) (Nõges \& Nõges, 1998). As a consequence of this disaster, about $20 \mathrm{t}$ of hibernating eels perished in the shallow southern tip of the lake. The other, more or less active, fishes managed to leave the place in time and survived.

\section{ACKNOWLEDGEMENTS}

This work was supported by projects of the Võrtsjärv Foundation (1992-99) and grant No. 4080 of the Estonian Science Foundation as well as by the European Union project ECOFRAME (contract EVK1-CT-1999-39). We are grateful to Mrs. Ester Jaigma, who kindly revised the English text of the manuscript.

\section{REFERENCES}

Arukaevu, K. (comp.) 1986. Eesti NSV jõgede, ojade ja kraavide nimestik. Valgus, Tallinn.

Downing, J. A. \& Plante, C. 1993. Production of fish populations in lakes. Can. J. Fish. Aquat. Sci., 50, 110-120.

Erm, V. 1981. Koha. Valgus, Tallinn.

Haberman, J., Nõges, P., Nõges, T., Pihu, E., Kangur, K., Kangur, A. \& Kisand, V. 1998. Characterization of Lake Võrtsjärv. Limnologica, 28, 3-10.

Huttula, T. \& Nõges, T. (eds.) 1998. Present State and Future Fate of Lake Võrtsjärv. Results from Finnish-Estonian Joint Project in 1993-1997. The Finnish Environment, 209 (Pirkanmaa Regional Environment Centre, Tampere).

Jaani, A. 1973. Hüdroloogia. In Võrtsjärv (Timm, T., ed.), pp. 37-60. Valgus, Tallinn.

Järvalt, A. 1990. Võrtsjärve kalastik. Eesti Loodus, 11, 719-722.

Järvalt, A. 1998. Estimation of fishing mortality and abundance of pikeperch Stizostedion lucioperca (L.) in Lake Võrtsjärv, Estonia, by Virtual Population Analysis. Limnologica, 28, 109-113.

Järvet, A. 2000. Water regime of Lake Võrtsjärv. In Estonia. Geographical Studies, 8, pp. 72-88. Estonian Academy Publishers, Tallinn.

Kangur, K., Timm, H., Timm, T. \& Timm, V. 1998. Long-term changes of the macrozoobenthos of Lake Võrtsjärv. Limnologica, 28, 75-83.

Kangur, P., Kangur, A., Pihu, E. \& Jaani, A. 2000. Fluctuations of water level and catches of pike, Esox lucius L., in Lake Peipsi in recent decades. In Nordic Hydrological Conference (Nilsson, T., ed.), 1, pp. 51-57. Uppsala, Sweden. 
King, M. 1997. Fisheries Biology, Assessment and Management. Fishing News Books, Blackwell Science, Oxford.

Kiviste, A. 1999. Matemaatiline statistika MS Excel keskkonnas. GT Tarkvara, Tartu.

Leach, J. H., Dickie, L. M., Shuter, B. J., Borgmann, U., Hyman, J. \& Lysack, W. 1987. A review of methods for prediction of potential fish production with application to the Great Lakes and Lake Winnipeg. Can. J. Fish. Aquat. Sci., 44 (Suppl. 2), 471-485.

Le Cren, E. D. 1987. Perch (Perca fluviatilis) and pike (Esox lucius) in Windermere from 1940 to 1985; studies in population dynamics. Can. J. Fish. Aquat. Sci., 44, 216-228.

Lehtonen, H., Rahikainen, M., Hudd, R., Leskelae, A., Boehling, P. \& Kjellman, J. 1993. Variability of freshwater fish populations in the Gulf of Bothnia. Aqua Fenn., 23, 209-220.

Mills, C. A. \& Hurley, M. A. 1990. Long-term studies on the Windermere populations of perch (Perca fluviatilis), pike (Esox lucius) and arctic charr (Salvelinus alpinus). Freshwater Biol., 23, 119-136.

Mäemets, A. 1973. Kõrgem taimestik. In Võrtsjärv (Timm, T., ed.), pp. 77-82. Valgus, Tallinn.

Nõges, P. \& Nõges, T. 1998. The effect of fluctuating water level on the ecosystem of Lake Võrtsjärv, Central Estonia. Proc. Estonian Acad. Sci. Biol. Ecol., 47, 98-113.

Nõges, T., Nõges, P. \& Järvalt, A. 2000. Veetaseme mõju Võrtsjärve ökosüsteemi seisundile ja kalavarudele. In Problems of Contemporary Ecology, 8: Naturalistic Outlook of the Estonian Earth Day (Frey, T., ed.), pp. 137-145. Tartu.

Pihu, E. 1959. Kalade kudemisest Võrtsjärves 1956. ja 1957. aasta kevadel. In Eesti NSV Teaduste Akadeemia juures asuva Loodusuurijate Seltsi aastaraamat, Vol. 51, pp. 225-248. Eesti Riiklik Kirjastus, Tallinn.

Pihu, E. 1998. Fishes and fisheries management in Lake Võrtsjärv. Limnologica, 28, 91-94.

Wolnicki, J., Myszkowski, L. \& Kaminski, R. 2001. The influence of water temperature on the growth, survival, condition and biological quality of juvenile burbot, Lota lota (L.). Arch. Pol. Fish., 9, 79-86.

\section{Veeseisu mõju Võrtsjärve kalavarudele ja -saakidele}

\section{Ain Järvalt ja Ervin Pihu}

Võrtsjärv on suur (pindala $270 \mathrm{~km}^{2}$ ) ja madal (suurim sügavus 6,0 m) eutroofne kohajärv. Tähtsamad töönduskalad järves on latikas, angerjas, koha ja haug, teisejärgulise tähtsusega on ahven, särg, kiisk ja luts. Kevadine kõrge veeseis laiendab haugi kudemisalasid ja avaldab tugevat positiivset mõju haugi uue põlvkonna arvukusele. Samal ajal suurenevad latikasaagid, sest mõrdu saab paigutada latika koelmutele lähemale, ja arenevad külmaveelise lutsu tugevad põlvkonnad. Kohal tekivad arvukad põlvkonnad madalaveelistel aastatel. Siis toimub kudemine varem, kohamaimud kasvavad kiiremini ja lähevad rööveluviisile juba esimesel elusuvel. Madala veeseisu ja karmi talve puhul võib järves kalu massiliselt surra. 